\title{
Lost Books, Lost Libraries, Lost Everything? A Scandinavian Early Modern Perspective
}

\author{
Wolfgang Undorf
}

The aim of this article is to identity books circulating in Early Modern Scandinavia that cannot now be documented through surviving copies. This quest obviously raises serious methodological questions, in particular how much credence we can place on elliptical and often fragmentary archival sources. The first part deals with individual books and how far we can identify (or not) authors, titles and the editions in question. The second part will give examples of small and large, personal and institutional book collections that have disappeared in Scandinavia in the early modern period. Here, the historiographical value of supplementing bibliographical records with biographical information will be evident. Finally, the third part of this article is devoted to the quantitative dimensions of early modern Scandinavian book culture as they can be traced on the basis of lost books and collections, enhanced by a wide array of archival sources. Taken together, this information allows us to offer some potentially significant conclusions on the nature and volume of the early modern North European book trade.

These remarks draw on a wider survey undertaken as part of a comprehensive search for evidence of book culture in the first era of the printed book. ${ }^{1}$ Here I take an inclusive approach, not ignoring the significant evidence of the circulation of print images which do not always fall within the normal definitions adopted for the study of books. Woodcuts were published as parts of the works of Saint Birgitta, usually consisting of a number of woodcut representations of Brigittine iconography produced in The Netherlands and distributed to Sweden. These had a significant impact on Scandinavian visual and religious cultures, as did engravings of works by Albrecht Dürer, the Master E.s. and other artists. The latter once served as models for mural paintings or have been pasted-in components of Brigittine manuscripts. Usually, the originals have been lost. Sometimes copies have survived on the walls of mediaeval churches, though more usually only the space is marked where an engraving had once

1 Wolfgang Undorf, From Gutenberg to Luther: Transnational Print Cultures in Scandinavia 1450-1525 (Leiden: Brill, 2014), especially the chapter 'Religious Movements and Print Culture: Woodcuts, Broadsheets and Books', pp. 278-293. 
been exhibited. Be that as it may, these traces are important testimonies to the visual worlds of churches and monasteries and the ways the printing press could answer to their needs. ${ }^{2}$

\section{Lost Books}

The Malmö List is an inventory of books which has been dated to the early $1520 \mathrm{~s}$ and located to Denmark's then largest town, Malmö, in what today is southern Sweden. ${ }^{3}$ Usually, it has been connected with the Danish humanist and bookseller, Christiern Pedersen. It distinguishes itself from many contemporary book lists by the bibliographical quality of most of its entries. These contain fine specimens of lost books which are quite easy to identify, for example the volume containing numbers 195-196 on the list: "Item 1 psalterium Cisterciensis ordinis et unum diurnal eiusdem ordinis." ${ }^{4}$ The only titles which fit with this description are the Psalterium Cisterciense of 1486 and the Diurnale Cisterciense of about 1487-1488, both printed by Peter Drach II in Speyer. Another likewise easily recognizable title - thanks to the writer's bibliographically meticulous registration - is the Boecken van der missen ende anderverff corrigeeret (no. 104), the second edition of this book printed in Antwerp about 1509. ${ }^{5}$

The inventory that was recorded following the death in 1597 of Elisabet Vasa, Swedish princess and duchess of Mecklenburg, contains among others two wonderful examples of books which are lost now, yet still fully decipherable. ${ }^{6}$ The first entry has been spelled by the unknown German-speaking secretary or registrator "Würtzgartlin für die kranke Seelen" (no. 26), the second slightly deviant as "Wurtzgartlein für die kranken seelen" (no. 62). Otfried Czaika identified the first entry as two variants of Bock's book dated 1562 both

2 Undorf, From Gutenberg, pp. 299-305.

3 Johannes Lindbaek and Ellen Jørgensen, 'To bogfortegnelser fra det 16. Aarhundredes Begyndelse', Danske Magazin, 6.1 (1913), pp. 319-334; Henrik Horstbøll, Menigmands medie: Det folkelige boktryck i Danmark 1500-1840 - En kulturhistorisk undersögelse (Copenhagen: Kongelige bibliotek; Museum Tusculanums forlag, 1999), pp. 220-221. The manuscript belongs to Det Kongelige Bibliotek Denmark, Mogens Gyldenstjernes Arkiv, Indkomne Sager; Lindbaek and Jørgensen, 'To bogfortegnelser', p. 323. Ellen Jörgensen, 'Les bibliothèques Danoises au Moyen âge', Nordisk Tidskrift för Bok- och Biblioteksväsen, 2 (1915), pp. 332-351, here pp. 350-351.

4 Undorf, From Gutenberg, p. 331.

5 Ibid., p. 326.

6 Otfried Czaika, Elisabet Vasa. En kvinna på 15oo-talet och hennes böcker (Stockholm: Föreningen Biblis, 2009), pp. 33, 90 and 94. 
of which display the same distinctive spelling of Würtzgartlin. The spelling of the second entry however represents all later editions of the same book. Elisabet Vasa clearly owned two different copies of this work and it does not seem that the secretary confused the identity of the copies. It so happens that the binding of the Würtzgartlin is one of very few described explicitly as being bound in blue velvet embroidered with pearls ("in blaw sammit mit perlen gesticket"). The second copy has no physical details attached to it. The two different spellings of two different entries of one and the same work in the inventory, reinforce the assumption that a list of books, be it a posthumous inventory or a catalogue, might have been executed with enough meticulousness to allow the identification of specific editions of a printed work.

Hans Urne, provost of the cathedral at Odense and a wealthy man, bequeathed in his will of 1503 five diurnals to poor priests. ${ }^{7}$ Apparently these five anonymous diurnals represent a lost edition. Circumstantial evidence allows us to make an approximate identification of this edition. In the year 1505, Jørgen Urne, the brother of the then deceased Hans Urne, was involved in a legal case with the otherwise completely unknown printer Simon Brandt. Brandt had been engaged by Hans Urne to print a number of books. ${ }^{8}$ This legal document contains an interesting passage, telling us that

Jørgen Urne spoke to Simon Brandt about diurnals which he had printed for Master Hans Urne, and he said that they haven't been printed correctly and that they were dated at a year, when they couldn't possibly have been printed. ${ }^{9}$

7 'Om Mester Hans Urne Som Prost i Odense, og hans Testamente 1503', Danske Magazin, 1.10 (1745), pp. 289-300.

8 Wolfgang Undorf, 'Printing in the Danish Town of Odense', in Benito Rial Costas (ed.), Print Culture and Peripheries in Early Modern Europe. A Contribution to the History of Printing and the Book Trade in Small European and Spanish Cities (Leiden: Brill 2012), pp. 223-248.

9 "Da tiltalte Jørgen Urne Simon Brandt for Diurnaler, som hand trykte for Mester Hans Urne, og sagde han, at de ikke vare ret trykte, og komme til Aars, hvor de ikke kunde vorde trykte. Begierte saa Simon Brandt at faae samme Bøger igien for det de kostede, da swarede Jørgen Urne, at han det ei kunde giøre, hvorfor han samtykte at betale de anden halve Deel for fornævnte Diurnaler, bleve de saa venlig forligte”; 'Om Mester Hans Urne', pp. 299-300. The slightly different edition of this document published by Bruun does not change the meaning of these lines: "Da tiltalede Jörgen Urne Simon Brandt och sagde, at hand haffde trykt Diurnaler for M. Hans Urne, och vare de icke ret trykte, och komme til Aars, hvor de icke kunde derfor vorde soldte. Da svarede Simon Brandt, och begierede, at hand maatte faae samme Böger igien for det som de kostede. Da svarede Jörgen Urne, at hand det ey kunde giöre, hvorfore han och samtyckte at betale den anden Deel for forneffnte Diurnaler etc. 
There are no records of a diurnal printed in Denmark - as suggested by this archival source - or abroad until several years later: the Diurnale Roschildense of 1511 and the Diurnale Slesvicense of 1513, both commissioned and edited by Christiern Pedersen and printed by Jean Badin in Paris. Two editions of the North German Diurnale Lubicense had been printed in Lübeck at the end of the fifteenth century: the first by Johan Snell around 1482, the second by Matthaeus Brandis around 1490 for Hans van Ghetelen. Johann Snell's edition has no impressum, and if there was one in van Ghetelen's edition, it has not been preserved. Jørgen Urne speaks explicitly of the discrepancy between the publication date of the Diurnale and the date claimed by the printer, which suggests that it was possible to establish the date the Diurnale was printed. Liturgical argument too speaks against the idea that the work sold to Urne was a copy of a Diurnale Lubicense.

A diurnale indicated clearly the diocese or religious order whose rite it followed, and for that reason, distributing a liturgical work intended for one diocese to another diocese would have been an error far worse than a simple misprinting of the date of publication and would surely have merited specific comment by Jørgen Urne. This suggests that Brandt had tried to sell Hans Urne recycled or somehow altered copies of an unknown Diurnale Ottoniense. Simon Brandt offered to take back all copies of the Diurnale in question and to reimburse Jørgen Urne, who rejected this offer. We can conclude from the discussion of the incorrect printing date above that Jørgen Urne or his brother Hans had seen the books in question, and it is quite possible that copies had already been distributed. The Diurnale produced by Simon Brandt might not have been altogether useless to its potential purchaser, but it has definitely disappeared.

Hans Urne bequeathed of a quite remarkable book collection in his will of the year 1503. Among more than 260 books mentioned, we find a large number of references to the following literary genres:

- 3 books of prayer,

- 8 chronicles,

- 2 German chronicles,

-5 diurnals,

-2 gradual,

- 30 liturgical handbooks,

Bleffue saa venlige och vel foreenede etc."; Christian Bruun, 'Den danske Literatur fra Bogtrykkerkonstens Inførelse i Danmark til 1550', Aarsberetninger og Meddelelser fra Det Store Kongelige Bibliothek, 1 (1864-1869), pp. 109-111, 111. 
- 1 manual, and

-200 schoolbooks.

Only further archival evidence could help us make more out of this than a list of literary genres typical for early sixteenth-century religious book culture. The books above were bequeathed to members of Hans Urne's family, to friends and institutions. As far as we know from provenance registers, none of the books has survived. But that they once existed bears witness to the wealth of books available to Hans Urne in a so-called 'provincial' town of Denmark.

During the earliest period of the process of transition from Catholicism to Protestantism, Lutheran works were imported by means that were largely informal, private and illegal. Significant witness of this traffic is found in letters written by Hans Brask, bishop of Linköping. ${ }^{10}$ We have no knowledge (so far) of specific Lutheran or other 'heretical' books that came to Sweden during the first half of the 1520 s, but Brask seems to have owned or at least had access to a number of such works, which he industriously quotes in his letters. In a letter to his colleague Magnus, the newly elected bishop of Skara, Brask points out the importance of studying Luther's works and pro-Lutheran tracts, which seem to have been readily available to him. ${ }^{11}$ These are usually referred to in general terms only; he becomes much more specific, though, in referring to anti-Lutheran books, especially a work against the Ruthenian heresy or the $15^{21}$ Rome edition of Henry VIII's Assertio septem, which had been sent to Brask directly from Rome in 1523 .

Brask was not the only one to make use of private channels for the importation of books into Sweden. In a letter dated 6 June 1524, he informed the citizens of Söderköping that they were forbidden to sell, buy or distribute Luther's books. ${ }^{12}$ According to Brask, foreign merchants and other individuals had been importing such works into the country and the diocese of Linköping for some years, apparently through the port of Söderköping. It seems as if we have lost all these smuggled books as well as Brask's own copies. However, they once formed part of Early Modern Swedish book culture. Brask was well acquainted with domestic and foreign book production, as we can read from among other

10 Per Stobaeus, Hans Brask: en senmedeltida biskop och hans tankevärld (Skellefteå: Artos 2008); Hedda Gunneng, Biskop Hans Brasks registratur: textutgåva (Uppsala: Hedda Gunneng 2003).

11 Gunneng, Biskop Hans Brask, no. 193, dated 28 March 1524, and no. 194, dated 29 March 1524.

12 Ibid., no. 228. 
sources, a letter he wrote to Margareta, the sister of the newly elected Swedish king Gustavus Vasa:

When we last visited Stegeborg castle for consultations, we spoke of so many German and Swedish books that I don't fully remember which ones you desired, but we send you now by return of post a German passion. ${ }^{13}$

It is no surprise that a copy of a German Passionale that once belonged to Margareta Vasa has not been preserved. And we will never know which German and Swedish books the two talked about and where they had got information about them in the first place.

\section{Lost Libraries}

Herrevad monastery in then-Danish Skåne was founded by Cistercians as early as 1144. We know nothing of its library, but we do know of some books once at the disposal of one of its monks. Between 13 and 15 February 1525, Hans Brask, the last Catholic bishop of the diocese of Linköping in Sweden, wrote to the abbot of Herrevad monastery about a lawsuit in his diocese. ${ }^{14}$ Brask's letter, a response to a letter from the abbot on behalf of a certain Brother Andreas who had appealed to the authority of the bishop, describes the circumstances of this exchange of letters.

While on a journey through Sweden - the details are not specified - Brother Andreas had left personal belongings in the custody of a certain Gudmund of Ryeholm (probably Ryholm opposite Vadstena, on the western shore of Lake Vättern). Brother Andreas was now appealing for the return of his possessions, among which were a number of items that might seem somewhat surprising to find in the possession of a Cistercian monk: a sum of money, fine clothes, a bath towel, shaving instruments, and saddlery. (This Cistercian monk seems to have sprung from a Protestant, anti-Catholic caricature.) Of particular interest for this study is a list of seven books contained in two travel bags belonging to Brother Andreas (table 5.1).

13 "Tha vi vore senest til samtal pa Stegeborg var pa tall om monge böker tydzsche oc swensche saa at oss ey fullelica drager til minnes ther om edra begäre doch sende vi eder nu med thetta samme bud eth tyst passional"; ibid., no. 182.

14 Ibid., no. 308: "Casum autem fratris Andree tum vestre fraternitatis tum ipsius domini Andree intuitu quamprimum dabitur occasio sic dante domino absolveus". 
TABLE 5.1 The books belonging to brother Andreas

Author/title Print

Orationale $=$ Hieronymus de Villa Vitis Orationale

Donat.

Buccolicam Virgilii = Virgilius Maro Bucolica

Pupillam oculi = Johannes de Burgos Pupillam oculi Vocabularium iuris

Viridarium poetarum $=$ Viridarium ilustrium

Poetarum

Diurnale $=$ Diurnale Cisterciense $?$

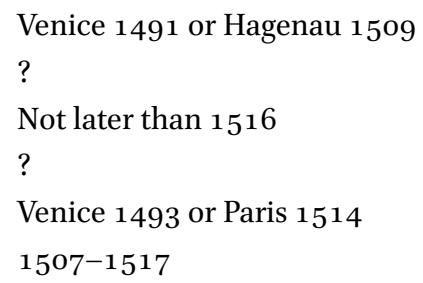

Speyer: Drach, 1486 ?

This list of books, short though it is, has a number of striking features. The titles seem to have been recorded fairly accurately, a quality the list shares with other early modern booklists. It is possible that these works belonged to the monastery and had been selected by Brother Andreas as reading matter for his journey, but neither Virgil's Buccolica nor the Viridarium illustrium poetarum, a collection of famous classical Latin poets, seems a likely candidate for inclusion in a Cistercian library, unless the study of classical authors was much more common than previously known. It seems more likely that these books might have been Brother Andreas' personal possessions. The Orationale and the Diurnale would have enabled a Cistercian monk to perform his daily religious routines.

The inclusion of Johannes de Burgos' Pupillam oculi, an essential text on the administration of the sacraments, suggests that Brother Andreas was a priest, and the presence of 'vocabularium iuris' that he was conversant in legal matters. The remaining three titles are possibly linked: Brother Andreas could have studied classical Latin with the help of Virgil, a compilation of ancient poets and a Latin grammar, which would explain their presence in his pack. So far, no book in a contemporary Scandinavian collection has been identified as having once belonged to Brother Andreas.

The following case studies show some of the problems which a book historian can face with regard to early modern book lists. The first is that of a Swedish Dominican monk named Clemens Henricus Rytingh who left us three different lists of books which he himself had acquired or lent out to other people during the 1480 os. $^{15} \mathrm{He}$ owned at least 65 printed books. In this respect

15 Isak Collijn, 'Svenska boksamlingar under medeltiden och deras ägare. 2: Clemens Rytinghs boksamling och bokdepositioner', Samlaren, 24 (1903), pp. 125-140. 
his example goes a long way towards disproving any suggestion that Sweden would have lacked books during the incunabula period.

We begin with an archival conundrum: each of the three lists appeared within a different printed book, but these books themselves did not appear on the lists they contained. The first list can be dated 1484 or at the latest the beginning of 1485 . It is an inventory that also includes three manuscripts as well as personal belongings such as pictures and bed linen. Most important for us is the collection of 28 titles of printed books in 26 volumes. These are books which Rytingh, then perhaps still a member of the Dominican convent in Skara, bequeathed to confreres of his order, as well as churches and convents.

One unidentified book, which Rytingh had acquired in Lübeck, was given to an otherwise unknown Clemens Benedictus, and one book each to the Dominican monasteries in Stockholm and Västerås. The rest of the books were almost equally divided between two recipients: Gudmundus Benedicti, provost at Skara cathedral and later a member of the Dominican monastery in Skara, received 14 books, while 11 were given to Laurentius Magnus, one of the most important members of the Dominican monastery in Stockholm at the end of the fifteenth century.

The second list is dated 1485. It does not represent a donation of any kind, but an astonishingly generous loan from Rytingh to Skara Cathedral library (the particular circumstances of this loan are not known). The list contains 18 titles in 22 volumes. Two thirds of the books were also mentioned on list A, representing there books donated "In manibus fratris gudmundi benedicti", i.e. to Gudmundus Benedicti, the aforementioned provost of Skara Cathedral. Not all books given to Gudmundus in 1484 appear on list B. Indeed, Gudmundus Benedicti does not appear at all in document $B$ except at the end, when the writer of list B states that "Item frater gudmundus benedicti Skarensis concessione habet Catholicon". The two books preceding the Catholicon were at the time of the loan in the hands of another user, too: "Dominus Matias sueta [!] cum licentia domini prepositi et lectoris fratris clementis [habet] Sermones alberti et Johannem de turre cremata super psalterium".

At least these three books had been lent to other people in Rytingh's monastic and ecclesiastical network. Does this mean that all the books given to Gudmundus in 1484 were only a loan? The passage in document A was crossed out later, so the books left in the hands of these confrères were meant to remain the property of Rytingh and were then disposed of in a different way. The least one can say is that lending large numbers of books without giving up right of ownership seems to have been not at all unusual. This also means that books, from single volumes to collections of books, moved freely between members of an intellectual-literary network. But neither the wording of both lists nor the 
crossing out of relevant parts of document A rule out other assumptions. Part 2 of Brundelsheim's collection of sermons might or might not be the same copy as the one mentioned in the third list, and the copy of Johannes de Tambaco's Liber de consolatione theologiae might indeed be different from the copy preserved in Uppsala University Library which had belonged to Laurentius Magnus. Later, there is one book given to Laurentius Magnus in Stockholm which might be regarded as a loan too, because it appears on list $C$ of Rytingh's books dated about 1487. This might simply have been a new acquisition, since Rytingh had given away his first copy to Laurentius Magnus.

The last list has been dated about 1487. Its sole purpose was to document the books in Rytingh's possession at that time: "Libri infra scripti sunt fratris Clementis Rytingh ordinis predicatorum lectoris Stokholmensis". Rytingh had then definitely moved from Skara to Stockholm. The list contains 38 titles in 34 volumes, among them 10 books which might be identical with books previously lent to Skara Cathedral library and Gudmundus Benedicti. The rest, more than two thirds of the books, are either new acquisitions made since $1484 / 5$ or simply parts of Rytingh's library which had not been the subject of earlier transactions and had therefore never before been registered.

The number of books acquired by Rytingh to replace titles which he had given away is limited. He bought a second copy of Albertus Magnus, Mariale as well as another copy of the Sermones de tempore by Brundelsheim. Even after this, books continued to circulate within the religious-ecclesiastical circles in which Rytingh himself moved. Two books were later integrated into Vadstena monastery library, recognizable by its characteristic shelf-marks: Busch's Speculum exemplorum and the sermons of Hugo de Prato Florido. Another title was earmarked for Uppsala cathedral, Leonardus de Utino's Sermones de sanctis, "qui post mortem eiusdem domini fratris clementis pertinet ecclesie vpsalensj".

None of these three documents, and not even all three taken together, give a complete picture of Rytingh's book possessions over time. In addition to the aforementioned in all 64 titles there are four more (see table 5.2).

Rytingh's third book list is contained within his copy of Molitor's Tabula, but the text itself does not appear on that same list. Albertus Magnus and Bernoldus are bound together and now in Uppsala University library. They seem to have been part of the library of the Dominican monastery in Stockholm, then of King John III's college in Stockholm. Together with other parts of King Sigismund's private library, this volume was donated to Uppsala University library in 1620/1621. The provenances of the last book, containing the letters of Cyprianus, can be dated quite reliably. Printed ca. 1479, it was acquired by Rytingh after he had been appointed lecturer in theology, according to an annotation by his own hand: "Liber Fratris Clementis Rytinck ordinis predicatorum sacre theologie 
TABLE 5.2 Books owned by Clemens Rytingh not mentioned on lists $A-C$

\begin{tabular}{|c|c|c|}
\hline Author/title & Provenance & ID \\
\hline $\begin{array}{l}\text { Albertus Magnus Compendium } \\
\text { theologicae veritatis }\end{array}$ & "Liber lectoris fratris clementis rytingh" & 25 \\
\hline $\begin{array}{l}\text { Bernoldus Distinctiones de tempore } \\
\text { et de sanctis }\end{array}$ & "Liber lectoris fratris clementis rytingh" & 390 \\
\hline Cyprianus Epistolae & $\begin{array}{l}\text { "Liber Fratris Clementis Rytinck ordinis } \\
\text { predicatorum sacre theologie lectoris" }\end{array}$ & 1020 \\
\hline $\begin{array}{l}\text { Molitor Tabula super Summa } \\
\text { theologica Antonini }\end{array}$ & $\begin{array}{l}\text { "Liber lectoris fratris clementis Rytingh } \\
\text { ordinis predicatorum stokholmensis" }\end{array}$ & 2996 \\
\hline
\end{tabular}

lectoris". He may have given it to its second owner, Mathias, dean at Uppsala cathedral since 1487, before April 23, 1485. The second of his book lists mentions two books which then were in the hands of a "Dominus Matias", apparently the same person. ${ }^{16}$

In terms of content, Rytingh's books do not stand out from other theological collections of the same period. Other than two history books, Conradus de Alemania's philosophical Responsorium curiosorum and Vincent of Beauvais' Speculum naturale, Rytingh possessed only works that reflected his theological interests and professional needs as a monk and priest. The collection contained Biblical commentaries and repertories but apparently no edition of the Bible itself. The principal part of Rytingh's collection is made up of catechetical works both by authors frequently encountered such as Albertus Magnus, Angelus de Clavasio, Bernard of Clairvaux and Herolt and authors who were apparently less popular in Scandinavia, such as Johannes Gritsch, Johannes Busch and Conradus Soccus de Brundelsheim. Theological books make up about one quarter of this list, with the majority by high mediaeval and late mediaeval authors. The only liturgical book on the list is an unidentified psalter, yet this work would surely not have been the only liturgical book Rytingh owned or made use of during his lifetime. Liturgical books were often owned by religious institutions rather than by individuals. Among the few pedagogical titles we find bestsellers such as Donatus and Balbus' Catholicon.

Rytingh possessed a large and valuable book collection. At the time list A was drawn up, he had returned from his studies. He had begun lecturing at

$16 \quad$ Ibid., p. 133. 
Uppsala University at the beginning of the 1480 s and was a member of the Dominican monastery in Stockholm. Within only a few years of the appearance of the first booksellers in Sweden and the establishment of printing, Rytingh, like other Swedish customers, seems to have had access to a large variety of authors and titles. He seems also to have benefitted from the growing appeal of the Swedish book market to continental publishers and booksellers, with its customers in cathedral chapters, universities and schools.

We have now come to the not entirely surprising conclusion that not even three consecutive book lists can describe a book collection in its entirety. Actually, not even a post mortem inventory would have. There exists an inherent haziness in all these kinds of sources. Sources may not specify individual familiar items because their identity is known to all parties involved, or they do not include later acquisitions; perhaps books simply are not remembered at the time for the composition of a list. ${ }^{17}$ On Rytingh's book lists, books can appear once, twice or three times. Other books do not appear on any of the three lists, even though in one case a book is hiding one of the lists inside its covers. What we know today of the books once in the possession of Clemens Henricus Rytingh, is still nothing more than an approximation of the collection he might have accumulated during his lifetime. This is not the right occasion to talk about the network of individuals and institutions within which Rytingh's books were deposited, loaned and donated. Ten of his books have survived today, in Västerås, Uppsala and Stockholm. This means that there are at least 58 copies of books of well-known authors and content which have disappeared. Our knowledge about these books provides us with an insight into the wealth of books available in a remote region of Northern Europe at the end of the Middle Ages.

\section{Books owned by Clemens Rytingh but now lost}

Albertus Magnus Mariale s. de laudibus beatae virginis Mariae Albertus Magnus Mariale s. de laudibus beatae virginis Mariae Albertus Magnus Sermones notabiles de tempore et sanctis Albertus Magnus Super mulierem fortem Albertus Magnus Unknown title Alexander de Villa Dei Expositio super Doctrinale Alphonsus de Spina Fortalicium fidei contra hostes fidei christianae

17 Hans Urne's will contains a passage revealing that he had lent one of his brothers a number of books which he then did not remember in detail or did not bother to have then written down: "And altogether I give him what books I had lent him before" ["Og sammeledis huad Bøger ieg haffde hannem tilforne lett”]; 'Om Mester Hans Urne', p. 293. 
Angelus de Clavasio Summa angelica(?)

Antoninus Florentinus Chronicon s. opus historiarum

Aquinas Catena aurea s. Continuum in quatuor evangelistas

Balbus Catholicon

Bartholomaeus Pisanus de S. Concordio Summa de casibus conscientiae

Bernardus Claravallensis Homeliae super evangelio Missus est angelus

Gabriel

Bernardus Claravallensis Sermones

Bonaventura Diaeta salutis

Bonaventura Vita Christi s. meditationes vitae Jesu Christi

Caesarius Cisterciensis Dialogus miraculorum

Caracciolus Quadragesimale

Chrysostomus(?)

Conradus (Soccus) de Brundelsheim Sermones de sanctis

Conradus (Soccus) de Brundelsheim Sermones de tempore

Conradus (Soccus) de Brundelsheim Sermones de tempore

Conradus de Alemania Responsorium curiosorum

Conradus de Almania(?) [Unknown title]

Donatus Expositio super Donatum, De octo partibus orationis

Gerson Opera. P. 1-4

Gritsch Quadragesimale

Herolt Liber de eruditione Christifidelium

Hieronymus Vitae patrum

Hugo de Sancto Caro Postilla super IV evangelia

Johannes de Tambaco Liber de consolatione theologiae

Johannes de Turrecremata Expositio super toto psalterio

Lyra Glossae in universa biblia

Lyra Moralia super totam bibliam

Lyra Repertorium in postillam Nicolai de Lyra

Marchesini Mammotrectus super bibliam

Molitor Tabula super Summa theologica Antonini

Nider Praeceptorium legis s. expositio decalogi

Nider Sermones de sanctis

Passionarius cum additamentis

Paulus Burgensis de S. Maria Dialogus qui vocatur Scrutinium scripturarum

Petrus Bergomensis Tabula super omnia opera Thomae Aqvinatis

Petrus Comestor Historia scholastica

Petrus de Palude Sermones thesauri novi de tempore et de sanctis

Psalter

Rolevinck Fasciculus temporum 
Thomas Cantipratensis Bonum universale de proprietatibus apum(?)

Turrecremata De potestate papae et concilii generalis

Udine Quadragesimale aureum

[Unknown]

Vincentius Bellovacensis Liber laudem virginis gloriosae(?)

Vincentius Bellovacensis Speculum historiale

Vincentius Bellovacensis Speculum morale

Vincentius Bellovacensis Speculum naturale

Vita Katherine

My next example covers the inventory of an episcopal mansion on the island of Fyn in the diocese of Odense in Denmark (see table 5.3). ${ }^{18}$ Although the inventory seems to have been compiled in the early 1530 , the Reformation has left no mark on its contents. It is made up exclusively of Danish Catholic liturgical books and a spectrum of devotional and historical titles that are reminiscent of pre-Reformation book culture. A large number of titles and definitely the majority of the volumes registered are Danish works: the Breviarium Lundense and the Breviarium Roschildense, one or two versions of a Danish Book of Hours, Danish and Latin editions of Saxo Grammaticus, three copies of an unidentified Statuta synodalia, and, finally, twenty copies of a Danish Oraria. The presence of these titles reveals the spread of Danish books through the country irrespective of whether they had been printed in Copenhagen, Odense or Paris. A Parisian press seems to have been responsible for Bonaventura's Vita Christi and another, anonymous Vita Christi, two copies of Books of Hours which might indeed represent two different editions, and John Maior's In quartum sententiarum quaestiones.

The entries are substantial and appear bibliographically correct. The compiler of this list includes information on the binding of each book using a language that is very similar to that of the Malmö book list of the early 1520 . Overall the works contained in the Fyn inventory seem to have been of quite recent date. One title was definitely produced in the fifteenth century, although the works of Pius II, Gazio, the anonymously published statutes of a Danish diocese, Ogier le Danois and the Flores poetarum might have been printed in the fifteenth century as well. Certainly, though, the majority of the books date from the sixteenth century. About one fifth of the titles that can be identified

18 'Fortegnelse over endel Böger og andet Inventarium paa en Biskopsgaard i Fyns Stift', Aarsberetninger fra Det Kongelige Geheimearchiv, 4 (1866-1870), Tillaegg III: 1, pp. 38-39. Undorf, From Gutenberg, pp. 370-372. 
TABLE 5.3 Books owned by the bishop of Odense at his manor house on the island of Fyn

\begin{tabular}{|c|c|c|}
\hline Author/title & Date & Origin \\
\hline Bonaventura Vita Christi & $1510-1512 ?$ & Paris \\
\hline Breviarium Lundense & $15^{17}$ & Paris \\
\hline Breviarium Ripense & & Denmark? \\
\hline Breviarium Roschildense & 1517 & Paris \\
\hline Champier De triplici disciplina Medicina & $1508 ?$ & Lyon? \\
\hline Chronicle [German] & & Germany \\
\hline Erasmus Institutio principis Christiani & 16 th $\mathrm{c}$. & \\
\hline \multicolumn{3}{|l|}{ Evangeliariorum } \\
\hline Flores poetarum de virtutibus et vitiis & $15^{\text {th }}$ c. $-15^{17}$ & Cologne? \\
\hline Gazio Florida Corona & $1491-1516$ & Lyon or Venice? \\
\hline Hora [Danish] & 16 th c.? & Copenhagen or Paris? \\
\hline Hora [Danish] & & Paris? \\
\hline Hora $[$ Latin] & 16 th c.? & Copenhagen or Paris? \\
\hline Hora [Latin] & & Paris? \\
\hline Ludolphus de Saxonia Vita Christi? & 16 th c.? & Paris? \\
\hline Maior In quartum sententiarum quaestiones & $15^{09-1519}$ & Paris \\
\hline Ogier le Danois & $1498-15^{25}$ & France \\
\hline Oraria $[$ Danish $]$ & 16 th $\mathrm{c}$. & Copenhagen or Paris? \\
\hline \multicolumn{3}{|l|}{ Orationes de sanctis } \\
\hline Petrus de Montagnano Fasciculus medicinae & $15^{13}$ & Venice \\
\hline Pius II (Piccolomini) & $15^{\text {th }} \mathrm{c} . ?$ & \\
\hline Policratici contenta & 1513 & Paris \\
\hline $\begin{array}{l}\text { Quadragesimale et adventuale De arte } \\
\text { moriendi }\end{array}$ & 1488 & Antwerpen \\
\hline $\begin{array}{l}\text { Riccius De Regibus Galliae, Hispaniae, } \\
\text { Hierosolymi, Siciliae et Hungariae }\end{array}$ & $1517 ?$ & Basel? \\
\hline $\begin{array}{l}\text { Saxo Grammaticus Danorum Regum } \\
\text { heroumque historia }\end{array}$ & $1514 ?$ & Paris? \\
\hline Saxo Grammaticus De denscke Kroneke & 1502 & Odense \\
\hline Statuta synodalia & $1496-1517$ & $\begin{array}{l}\text { Lübeck, Copenhagen } \\
\text { or Paris? }\end{array}$ \\
\hline
\end{tabular}


were most probably printed in Copenhagen. About half of all identified titles may have been imported from France and in particular from Paris. A title such as the popular Ogier le Danois may well have been part of a delivery of books from Paris arranged by Jean Badin in the late 1510 s or by Christiern Pedersen in the early 1520 . The remainder of the identified works were printed in Cologne, Basel, Venice or other centres of Western European printing.

The Fyn inventory records the contents of a single episcopal household collection. It is indicative of both the bishop's personal interests and his wider responsibilities both within his household and to the clergy of his diocese. As head of the diocese of Odense, the bishop was involved in the supply and regulation of the printed material required by parishes and clergy. He apparently stocked multiple copies of certain books that would then have been distributed among or sold to clerics, in this case the Breviarium Ripense, twenty copies of the Danish Oraria and three Statuta synodalia. The presence of three medical works in this collection - a Vocabularius medicine that may have been

TABLE 5.4 The Fyn inventory according to literary genre

\begin{tabular}{lc}
\hline Content & Titles \\
\hline Religious literature & 16 \\
Bible & - \\
Catechetical & 1 \\
Devotional & 9 \\
Ecclesiastical & 1 \\
Liturgical & 3 \\
Theology & 2 \\
Secular literature & 11 \\
Classical & 1 \\
History & 4 \\
Humanism & 1 \\
Law & - \\
Pedagogical & 1 \\
Philosophy & - \\
Politics & - \\
Popular & 1 \\
Sciences & 3 \\
Total & 27 \\
& \\
\hline
\end{tabular}


Champier's De triplici disciplina Medicina or part of this work, Gazio's Florida corona (2), and Petrus de Montagnano's Fasciculus medicinae - may throw light on the bishop's educational background. It is possible that the Danish and Latin Books of Hours and the Danish and German chronicles were part of the literary life of the mansion's household.

At his mansion on the island of Fyn, the bishop of Odense had access to a small but assorted collection of printed books of almost all genres (table 5.4). Two third of the titles are in Latin and one third in Danish, with one title in French. We find Latin and Danish books in all categories. Although the devotional, ecclesiastical and historical literature is principally Danish, these works are not indicative of domestic Danish book production as they have largely been imported from Paris or German cities. The bishop had access to, and was evidently interested in, a mixture of quite up-to-date Danish and foreign literature.

\section{Lost Book Cultures}

All of this evidence of book possession raises the question whether it is at all possible to quantify the European book trade with Scandinavia in the preReformation period. Here archival evidence is scant, but still suggestive. In order to finance the equipping and maintenance of a warship in the 1490s, the city of Lübeck raised a toll, by the pound, on all goods leaving its harbor. This toll was recorded in the so-called Pfundzollbücher and spans the years 1492 to $1496 .{ }^{19}$ The toll is calculated in Pfennig, as one hundredth of each Mark Lübisch of the value of the cargo. Based on that toll, the value of each cargo can be easily recognized from the records - a toll of 9 Pfennig, for example, gives the value of the cargo in question as 9 Mark Lübisch. The Pfundzollbücher include details about barrels, boxes and drums filled with books leaving Lübeck for Denmark and Sweden, but they do not indicate the number of books in each container. We have only a very small number of sources that do address this issue. When the library of Henrik Matsson Huggut, secretary of the Swedish king Johan III, was confiscated in 1601 together with the rest of his property, the authorities registered 272 printed books in 309 volumes in three boxes. ${ }^{20}$ The Malmö List, which has been mentioned earlier, contains 283 records for a total of 3,164 books in all formats distributed over one box and 10 barrels, leading to an average number of 288 books per container, or 140 books per box and 302 per barrel.

19 Hans-Jürgen Vogtherr, Die Lübecker Pfundzollbücher 1492-1496, 6 vols. (Cologne: Böhlau 1996).

20 Terhi Kiiskinen, The Library of the Finnish Nobleman, Royal Secretary and Trustee Henrik Matsson (ca. 1540-1617) (Helsinki: Academia Scientarium Fennica, 2004). 
From the Scandinavian and North German sources available we can assume an average number of copies per box of 100 and an average number of books per barrel of about $150 .{ }^{21}$

If reckoned according to the average price of books in pre-Reformation Scandinavia no more than about 155 books would have been exported from Lübeck to Denmark and Sweden between 1492 and 1495. If, however, the calculation is based on an average number of books held by contemporary book containers, then that number would rise to 3,130. I am more inclined to assume that five years of book imports brought several thousand books to Scandinavia. Here we have reached a point where research results offer some suggestive indications of the quantitative outlines of a lost book trade.

The aforementioned Malmö list of books seems to originate from the confiscation of the collection sometime between 1523 and 1525 . It is usually connected with the Danish humanist, scholar, editor, printer and bookseller Christiern Pedersen. The Malmö List records 3,164 volumes, a collection on a remarkable scale in any European context. ${ }^{22}$ It is most probably not a private library: no individual owner would assemble hundreds of copies of individual titles; the list mentions no name other than Pedersen's and his were not more than eleven books. The combination of multiple copies of single titles and a majority of works in one or a few copies only, together with the explicit statement of every copy's state of binding points rather towards an effort to establish some form of bookshop. That outlet would have been aimed at a market and a clientele which included priests and preachers (we note a large number of editions of Sermones of various authors) and the local and regional schools (the collection included 753 copies of a so far unidentified Alphabeta), but also lay readers of devotional texts (the list records 1,165 copies of the Historia s. Clementis). It was not a homogeneous collection and included Danish books printed both in Denmark and abroad. Some of the books listed may not have been recent arrivals in Denmark at all: a number of titles can only be identified as incunabula editions printed in Germany several decades earlier, such as the Psalterium Cistercensis ordinis of 1486 or Conradus de Alemannia's Responsorium curiosorum of 1476. Such editions would have been either part of Pedersen's own library or had come from an antiquarian stock of books that had once belonged to other Danish book owners.

Other titles emanate directly from Pedersen's well-documented work as an editor and author in Paris, such as the Horce in Danica lingua and the Breviarium Lundense. Others document the trade in which Pedersen appears to have been

21 Undorf, From Gutenberg, p. 120.

22 Ibid., pp. 87-103, 321-335. 
involved since returning to Denmark. This group contains printed works that had been commissioned by Pedersen as well as titles that had been produced by other printer-publishers in Paris and sent to Denmark. Pedersen himself might have been the publisher of some of the anonymous titles recorded in the list, including schoolbooks such as the Abcdaria and Alphabeta, and liturgical books such as the Diurnale Lundense or the Psalteria. Later imports from Koberger in Nuremberg, many works printed in Lyons, and finally books with a variety of north European provenances complete the spectrum of printing evident in the Malmö List.

With regard to the theme of this volume, what did we lose in Malmö in the early 1520s? Certainly we lost a major early modern North European book collection - copies of a number of titles that appear on the Malmö List have survived, but none with provenances linked to the Malmö List or Christiern Pedersen (three books in the Danish National Library by Augustinus and Johannes Versor are linked by inscription to "Christiern Daa Malmö", probably identical with Cristiernus Malmogie, i.e. Christiern Pedersen, but they do not appear on the Malmö List!). We can also find a number of otherwise unidentified editions such as several Donatus, Remigius and other schoolbooks (nos. 76, 123, 206, 211, 225, 255, 257, 266), Psalters in different formats (nos. 85, 121, 191, 210, 232), books of hours in different sizes and languages (nos. 203, 205, $208,230,248,261,267,283$ ) and others. The list also includes a number of unidentified titles, such as the Gesta Francorum et Lombardorum (no. 55), the Diurnalia ad usum Lundensem (nos. 78, 120, 122), one Missa de nomine Jesu bound in cruda materia (no. 126) and Bonifacius de cena purificati ordinis minorum (no. 273).

\section{Summary and Conclusions}

Lost books as a field of research spans a wide variety of different types of loss, but in each case there are sources that might help us re-discover them. The more formal the source, the more reliable inventories seem to be. The more informal the source, on the other hand, the more bibliographical and physical dimensions we lose. The inventory of Elisabet Vasa from the end of the sixteenth century and the Malmö List of the early 1520 display at times a real understanding of the books in question and the bibliographical skills required to document works in quite an exact way. But the same book list might contain exact transcriptions side by side with what I would call rather vague indications of authors and titles. Informal sources such as private letters very often seem to contain only minimal amounts of information - here one thinks of 
the correspondence between Hans Brask and Margareta Vasa, the Swedish king's sister's referring to "so many German and Swedish books" in a letter dated 9 March 1524, or the same Hans Brask's complaint that year about Lutheran books that had been pouring into the city of Söderköping for some years.

Through all of these sources we have been able to identify a large number of books circulating in Scandinavia during this period, and evidence of a rich and varied print culture. The basis of my research is a database of now more than 6,80o Scandinavian pre-Reformation provenances, most of which are lost books. Collectively these findings transform our understanding of the book culture of the northern kingdoms in this period. To conclude with one single example: up to 1525 , only 119 titles were actually printed in all of Scandinavia. Compare this with the Malmö List that, apart from 14 or 15 Danish titles, contains more than 180 titles printed in other parts of Europe, that is, ten times as many. This leads me to two conclusions: first, Scandinavian history contains a multitude of archival sources which contain information on lost books; second, it is both feasible and fascinating to investigate them. 